International Journal of Instruction e-ISSN: $1308-1470 \bullet w w w . e-i j i . n e t$

Article submission code: 20201214083755

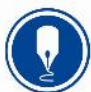

January $2022 \bullet$ Vol.15, No.1

p-ISSN: 1694-609X

pp. 311-326

Received: $14 / 12 / 2020$

Revision: $25 / 06 / 202$
Accepted: 19/07/2021

OnlineFirst: $24 / 10 / 2021$

\title{
Using Simulation on Project Based Learning in Minangkabau Culture Subject
}

\section{Zulfa}

Education Program, Padang State of University, Indonesia, zulfaeva75@gmail.com

\author{
Ahmad Nusi \\ M.Pd., State Polytechnic of Ambon, Indonesia, ahmad11minang@gmail.com
}

\section{Azwar Ananda}

Prof., Padang State of University, Indonesia, ananda.azwar4127@gmail.com

\section{Agusti Efi}

Prof., Padang State of University, Indonesia, gustti@yahoo.co.id

\section{Piki Setri Pernantah}

University of Riau, Indonesia, piki.setri@lecturer.unri.ac.id

This study aims to find a simulation project-based learning model for the Minangkabau Natural Culture subject in higher education. This research method uses the resarch and development ( $R$ and $D)$ development procedure using the Plomp development design that goes through 3 steps, namely: Preliminary Research, Prototyping Phase, and Assessment Phase. Samples were taken using purposive sampling technique. The research data were obtained using questionnaires, interview guides, tests, observation guides and validation sheets for each set of models developed. The research instrument was validated by an expert or expert. The data collected was processed and analyzed quantitatively and qualitatively. The PBPS model effectiveness test used parametric statistical analysis with the two-way ANOVA test. The results of this study indicate that the PBPS learning model in Minangkabau Natural Culture learning is valid based on the characteristics of the content, graphics and language in the PBPS learning model support system. The practicality test results on the one-to-one evaluation and the small group evaluation of the PBPS learning model tools meet practical criteria. The practicality of the PBPS model was felt by students, especially in several ways, including; (1) the stages of the learning process are easy to understand, (2) student books are very helpful for studying and understanding the Minangkabau Natural Culture material, and (3) the PBPS model tools are interesting to read and study.

Keywords: simulation problem-based learning (PBPS), minangkabau culture, research, development, learning

Citation: Zulfa., Nusi, A., Ananda, A., Efi, A., Pernantah, P. S. (2022). Using Simulation on Project Based Learning in Minangkabau Culture Subject. International Journal of Instruction, 15(1), 311-326. https://doi.org/10.29333/iji.2022.15118a 


\section{INTRODUCTION}

Achieving good educational output requires proper and complex learning design (Garvey \& Krug: 2015). The purpose of learning design is to evaluate and improve learning quality (Dwiyogo: 2018). An educator is strongly required to determine learning design should be used in learning (Pernantah, 2018). Learning design is an intentional effort to facilitate the learning process to achieve the learning goals (Fransyaigu, 2015). Implementing the learning design will highly affect students' ability (Joyce, et al.: 2011). In university, learning design obviously can be seen through the readiness of learning tools prepared by lecturers. The lecturer needs to prepare learning tools before starting learning activities each semester, such as lesson plans and teaching materials (Wicaksono, et al.: 2017).

Besides, obstacles and difficulties frequently occur during the implementation. The lecturer tends not to implement the project in the cultural study because it required time to prepare, especially for Minangkabau culture subject in university. The implementation is needed times and steps to follow. Another reason is the readiness of learning tools. It makes teaching and learning the Minangkabau culture subject difficult in higher education. It is challenging to implement Project Based Learning in class because the lecturer tends to ignore a model with complicated learning steps. ProjectBased Learning (PBPS) as learning models has characteristics that can construct learners' knowledge and skills (Barlenti, et al: 2017). The model is popular in the constructivism approach (Mayasari, et al: 2016). It provides learning experiences through project activities that lead to product creation (Ardianti, et al: 2017). Therefore, teaching with Project-Based Learning will create interesting and meaningful situations, also increase students' interest (Febrina: 2017); (Sucipto: 2017). The Simulation Project Based Learning Model (PBPS) is one of the models best learning in student self-study (Blumenfeld et al, 1991, English and Kitsantas 2013, and Hao, Maribe and Jensen, 2016), this model is effective to develop the necessary deep learning competencies to succeed in attaining a skill. Learning activities that are using projects and students as learning centers as principles. Basically (Zaremba et al, 2017) the PBP learning model is able to reconstruct student knowledge (Frank and Barzilai 2004). Through (1). Designing Projects, (2). Investigation of a wide range of realistic content (3) collaborative work that allows students to communicate ideas them and (4) produce products according to the results of the investigation.

The need analysis was conducted for the lecturers. Nusi, Ahmad \& Yelliza. (2020) argued need analysis done to collect information about a particular problem in teaching and learning. It found that $80 \%$ of lecturers have difficulties implementing the learning model, $80 \%$ using the learning model minimally, and $84 \%$ has used simulation but not the Project-Based Learning model. The detail showed in the following figure 1. 


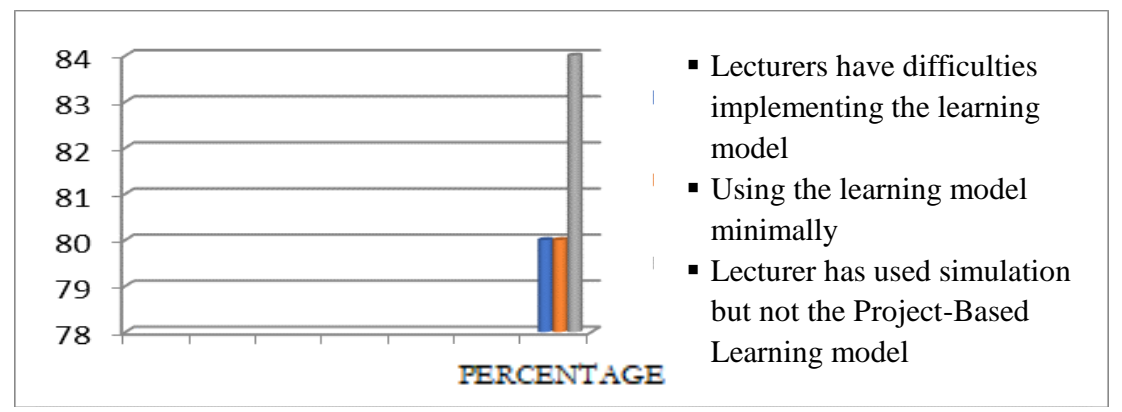

Figure 1

The need analysis of lecturers (Source: Research data, 2020)

Furthermore, the need analysis also conducted for the students discovered that $67.2 \%$ of the source, topic, and media of Minangkabau culture subject still provided by lecturers, so more than half of the students only wait for the explanation. Some lecturers have used the simulation in teaching Minangkabau culture subject. The learning was impactful of 91.2\% and using film and YouTube for $86.4 \%$. The detail showed in the following figure 2.

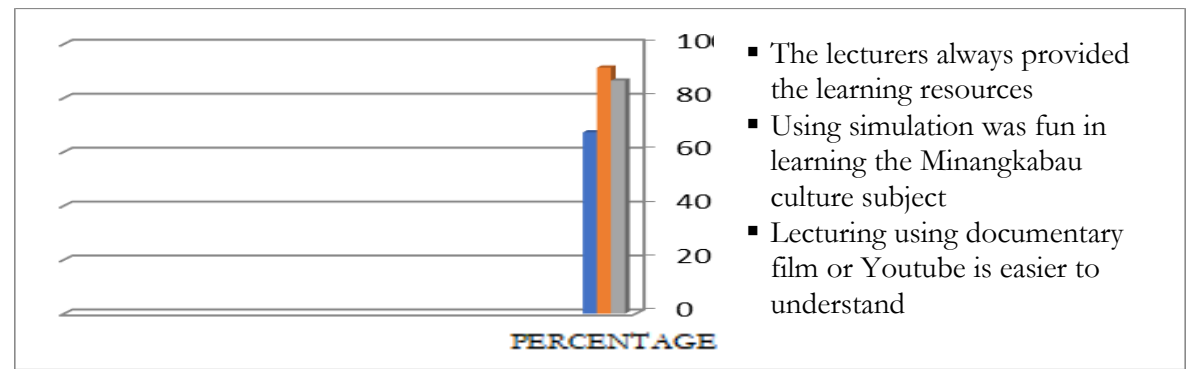

Figure 2

The need analysis of students (Source: Research data, 2020)

Based on the need analysis results, the problems in the Minangkabau culture class, both lecturers and students, should be studied. The Minangkabau culture subject is one of the most important subjects because it developed learning models based on local wisdom values of Minangkabau culture such as stories, legends, fairy tales that can shape students' characters (Eliza, 2017). Teachers have integrated character values of the religious and Minangkabau culture in learning at Vocational High Schools in South Solok (Afridinata, et, al: 2018).

Navis in Firdaus (2018) stated that the Minangkabau people were used nature as the life guide, regulated life norms, and guided thoughts and actions. A well-known proverb called Tigo Tali Sapilin viewed as the social system foundation in Minangkabau Culture, means that Minangkabau people were 'learning' from nature (Azwar, et al: 2018). Minangkabau ethnic is one of Indonesia's groups that preserve the Minangkabau culture (Malik, 2016). So, teaching Minangkabau culture is needed to strengthen the 
students' character and understanding of Minangkabau culture in higher education. Also, local institutions' role in maintaining various social changes in local Minangkabau communities is highly expected to contribute to local knowledge in managing local information resources in the community (Fadli, 2018). Therefore, the project-based learning model using simulation is needed to be studied on Minangkabau culture subject in higher education. The research aimed to develop project-based learning using simulation and test the effectiveness of learning model in the Minangkabau culture subject.

\section{METHOD}

\section{Research Design}

The research design was used Research and Development (R\&D) method (Borg, W.R. and Gall, M.D, 1989). It studied the project-based learning using simulation at Minangkabau culture subject in higher education.

\section{Research Subject}

The research subjects were students in the second semester of the Historical Education Study Program at Minangkabau culture subject for 2019/2020.

\section{Data Collection Technique}

Data collection techniques were participatory observation format or participant observation, documentation study that reviews the preliminary research related to the research problems. Furthermore, interviews and focus group discussions were done between lecturers, practitioners, and students to validate the learning model. Questionnaires and tests were given to measure the students' perception in implementing project-based learning using simulation and the impact on the character values.

\section{Research Procedure}

Based on (Akker, J.V.D., Bannan,B., Kelly A.E., Nieveen, N., dan Plomp, T, 2013), Research and Development design have 3 stages: 1) preliminary studies; 2) prototyping; and assessment. Referring to Plomp (2013), the following table showed the stage of project-based learning using simulation.

Table 1

The developing stage project-based learning using simulation

\begin{tabular}{|c|c|c|c|}
\hline No. & Developing Stage & Research Activity & Description \\
\hline 1. & $\begin{array}{l}\text { Preliminary } \\
\text { Research }\end{array}$ & Need analysis & $\begin{array}{l}\text { Gathering information related to the students' } \\
\text { information, curriculum, learning tools, and } \\
\text { documentation. Analysing the information and forming } \\
\text { the Project-Based Learning using Simulation }\end{array}$ \\
\hline \multirow[t]{2}{*}{2} & \multirow[t]{2}{*}{ Prototyping Phase } & Designing prototype & Designing Project-Based Learning using simulation \\
\hline & & $\begin{array}{l}\text { Formative } \\
\text { evaluation }\end{array}$ & $\begin{array}{l}\text { Conducting validity test (self-evaluation, expert review, } \\
\text { one to one evaluation, small group evaluation and field } \\
\text { test) on the prototype }\end{array}$ \\
\hline \multirow[t]{2}{*}{3} & \multirow[t]{2}{*}{ Assessment Phase } & Revision & Revising the prototype based on formative evaluation \\
\hline & & $\begin{array}{l}\text { Summative } \\
\text { evaluation }\end{array}$ & $\begin{array}{l}\text { Conducting practicality test and effectiveness of } \\
\text { prototype }\end{array}$ \\
\hline
\end{tabular}

(Source: Research Data) 
Furthermore, the development steps in this research are as follows:

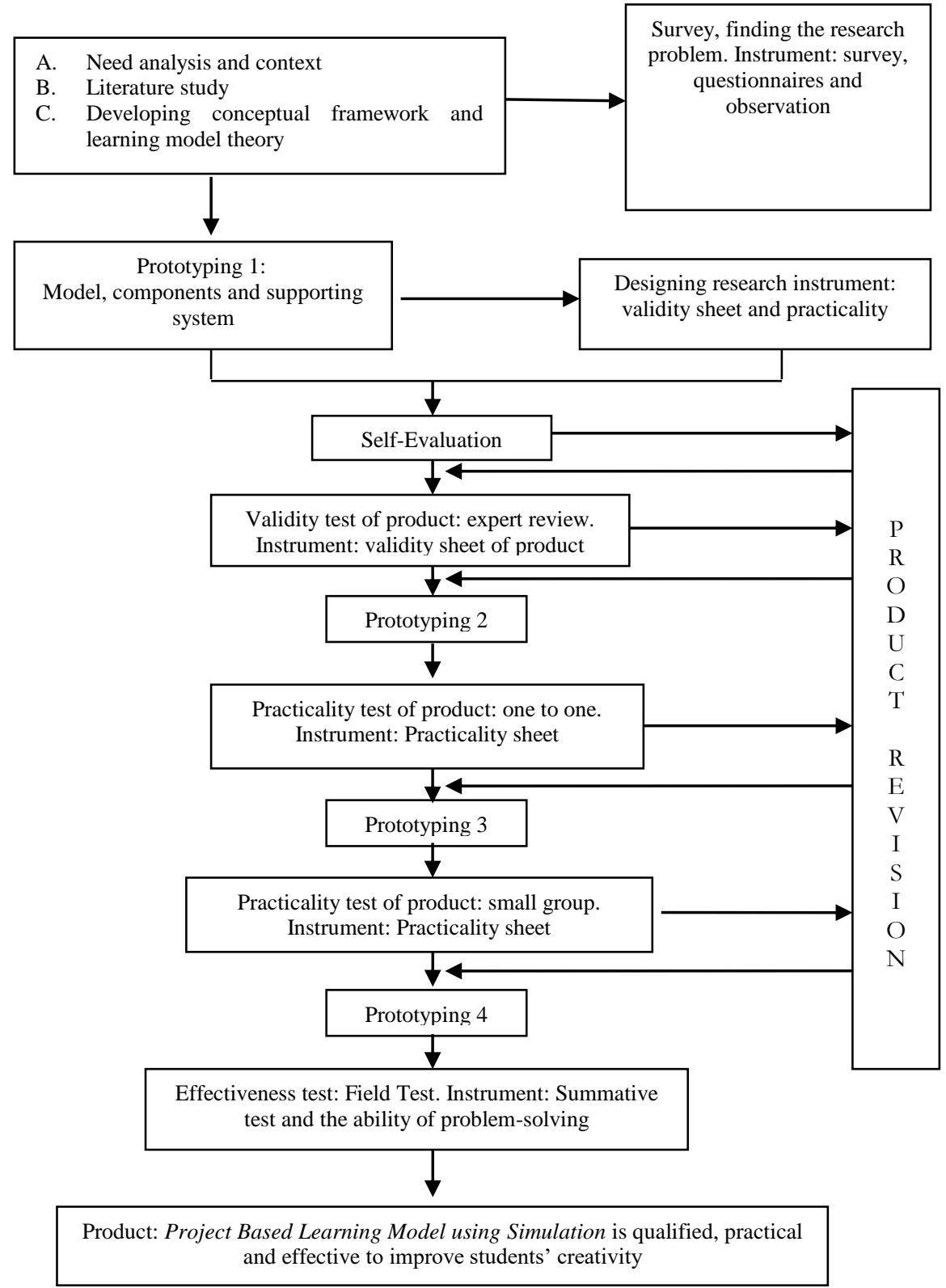

Figure 3

The procedure of development model

International Journal of Instruction, January $2022 \bullet$ Vol.15, No.1 


\section{FINDINGS}

The research result explained the development of the project-based learning using simulation based on Plump (2013) that contained 3 phases: 1) preliminary research phase; 2) prototyping phase; and assessment phase. The results described as follows.

\section{Result of Preliminary Research}

Preliminary research was conducted to examine the need analysis for lecturers and students. The need analysis for lecturers included: the difficulties in implementing the learning model, have used the learning model minimally and has used simulation but not the Project-Based Learning model (figure 1). The need analysis for students included: students just waited for the explanation given, and students enjoyed the learning using simulation and videos or YouTube (figure 2).

A pretest was carried before implementing the learning model, showed in the following table below.

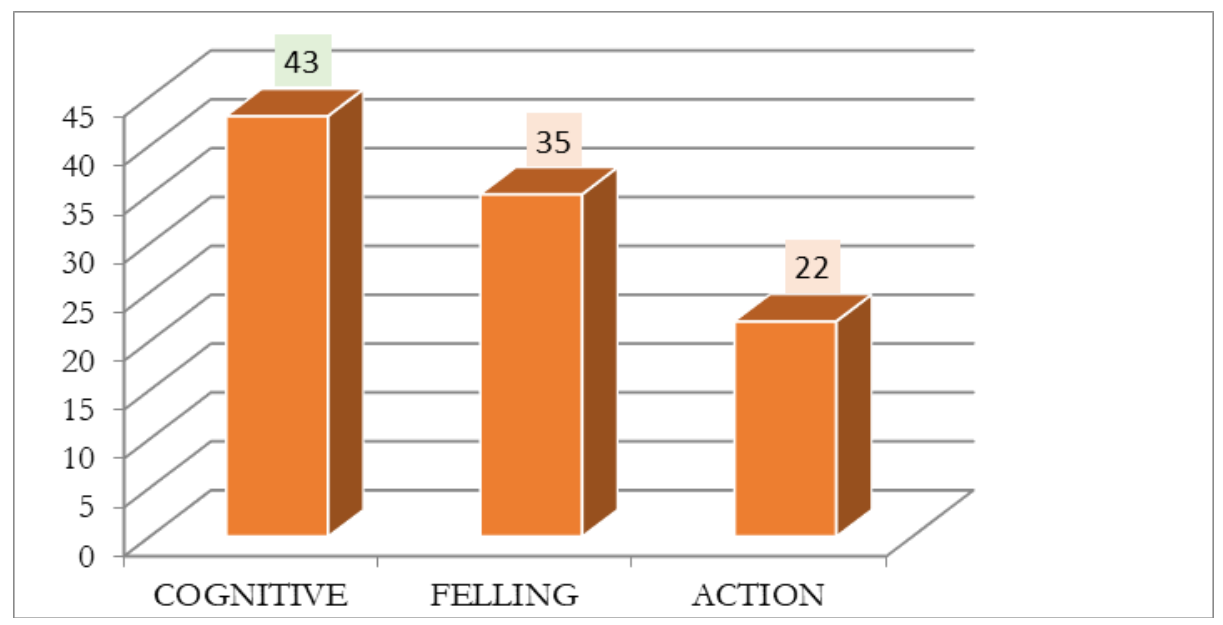

Figure 4

Summary of students' pre-test at minangkabau culture subject

(Source: Research data, 2020)

The pretest was conducted on students of class A and class B in the 6 semesters of the Historical Education Study Program, STKIP PGRI, West Sumatra. The result showed the learning outcomes without implementing the project-based learning using simulation in the Minangkabau culture subject were at the cognitive aspect of $43 \%, 35 \%$ in feeling, and $22 \%$ in action.

The implementation of project-based learning using simulation at Minangkabau culture subject was developed by experts, including Alyson Eisenhardt (2018) that used simulation to teach concept decision analysis on learning. Using scenario and simulation has proved as an effective method to train professionals in the classroom and the field 
(Galloway, 2009). Therefore, the simulation method is effectively used at Minangkabau culture subject. As a proverb said "alam takambang jadi guru" means to learn from nature.

Additionally, Eyikara (2017) stated that simulation is also an innovative teaching method to stimulate students' senses. Simulations can also be designed to reflect real-life conditions. Depends on the scenario, the simulation will guide students to some learning activities. It allowed students to practice repeatedly to master the skills, to learn independently, and accept mistakes. Simulation is an educational process that can replicate practice in a safe environment. Simulation can improve critical thinking and skills and implement into interactive learning (Eyikara: 2017). Therefore, the simulation model is impactful to be applied in the Minangkabau culture subject.

Lecturers have the main role in supporting the implementation of simulation as they organize learning plans and scenarios for simulations (Nurhayani, 2017). The simulation learning method has overgrown and has been used in several study programs worldwide and even in Saudi Arabia. The research by (Saied: 2017) studied student satisfaction and self-confidence in the learning regarding questionnaire (NLN, 2009) and general selfefficacy. The result showed significant differences in pre and posttest of knowledge and self-efficacy. Students were satisfied with the simulation experience, and the confidence was improved after. Satisfaction is also positively correlated with self-confidence. Due to the short time on pretest and posttest, the study provided information to understand the effect of simulation on students' knowledge, self-efficacy, and self-confidence (Hala Saied: 2017). Based on the study by (Galloway, 2009), (Evrim Eyikara: 2017), (Hala Saied: 2017), project-based learning using simulation can be used at Minangkabau Culture subject.

\section{Result of Prototyping Phase}

Based on the preliminary phase results, it was concluded that the existing learning model did not meet the Minangkabau cultural learning criteria. Thus, it is necessary to develop a learning model that can accommodate the needs and principles of higher education learning. The development of project-based learning using simulation has been adapted to the development level and student's needs. The learning model adopted the theory and findings by The George Lucas Education Foundation and Dopplet (2014) stated the importance of project-based learning using simulation to increase students' motivation and character values.

Here are some analyzes conducted in the application effectiveness test PBPS learning model.

\section{a. Normality test}

Analysis of the normality test in this study using the Lilliefors Test. The normality test hypothesis in this study refers to on the Reject criteria H0 if Lhitung $\geq$ Ltabel, accept H0 if Lhitung <Ltabel. If $\mathrm{H} 0$ accepted means the research sample data comes from distributed populations normal. 


\section{b. Homogeneity test}

Homogeneity test analysis in this study using the Bartlett Test. The homogeneity test hypothesis in this study. If the value of Fcount <Ftable. If $\mathrm{H} 0$ is accepted it means the variance of the study sample in groups 1,2 , and 4 was homogeneous.

\section{c. Two ways ANOVA test}

Two-way ANOVA test was used to see the difference in the mean (average) of the data more than two groups from the experimental and control classes. Hypothesis Two-way ANOVA test in this study is reject $\mathrm{H} 0$ if the value of Fcount> Ftable.

The component of the project-based learning model using simulation can be seen below:

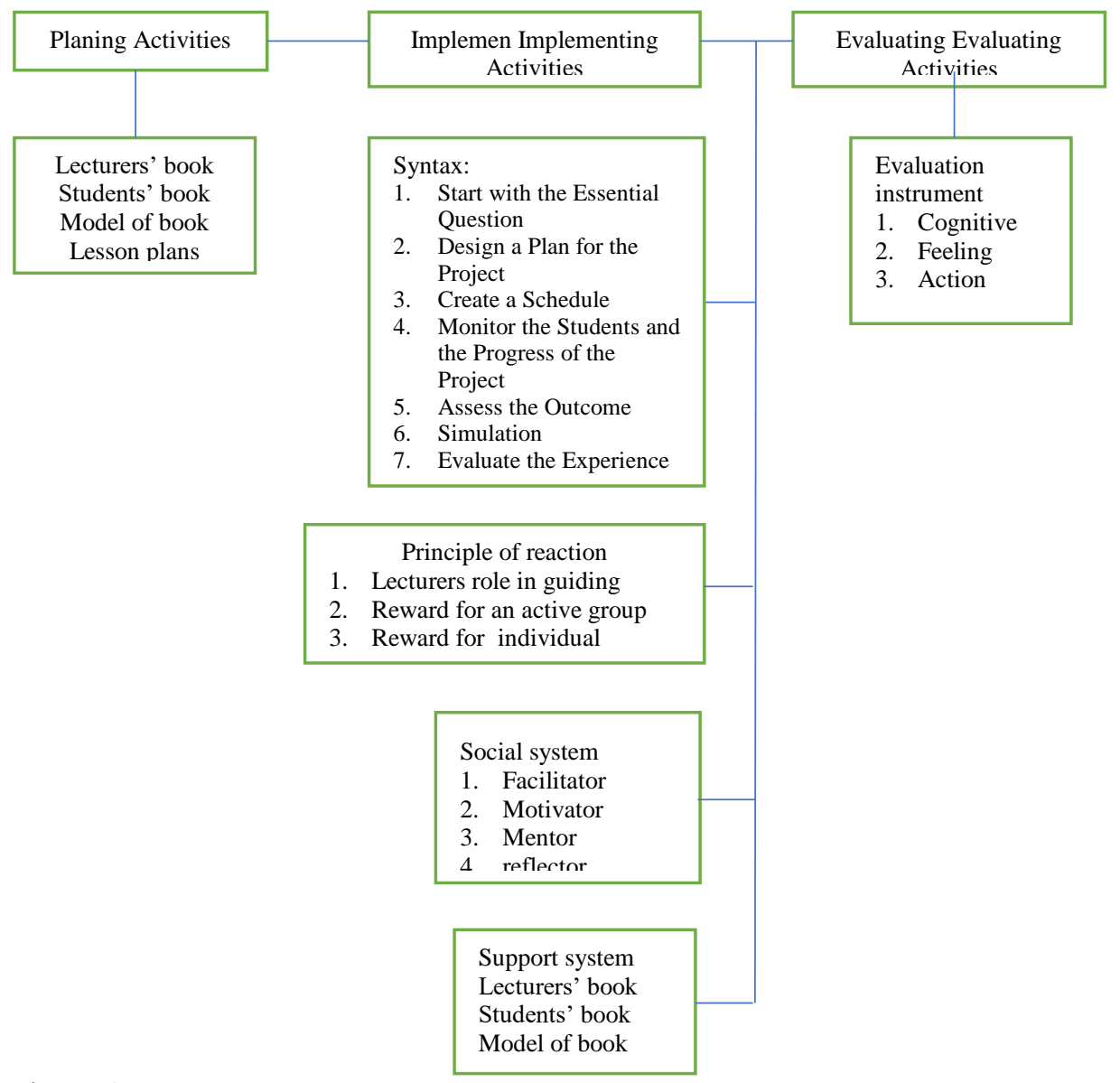

Figure 5

The component of the project-based learning using simulation 
This learning model is a new learning innovation in higher education, integrated with local wisdom. Another research from Arsih et al (2019) stated that the values of Randai (theatrical arts) could be integrated with problem-based learning to form innovations in the learning. Randai is one of the Minangkabau cultures with many moral values , impacting students' character.

\section{a. Validation test for model book}

The project-based learning using simulation was validated by 9 validators. It obtained an average rating validity of the $\mathrm{V}_{\text {aiken }} \geq 7.6$, which means the learning model developed meets the content validity with some improvements. The results showed in the following table.

Table 1

The validator rating result

\begin{tabular}{llll}
\hline No & Assessment Aspects & Validity Index of Aiken & Desc \\
\hline 1. & Syntax & Average $\geq 0,95$ & Valid \\
\hline 2. & Social system & Average $\geq 0,95$ & Valid \\
\hline 3. & Principles of reaction & Average $\geq 0,90$ & Valid \\
\hline 4. & Support system & Average $\geq 0,86$ & Valid \\
\hline 5. & Instructional dan natural effects & Average $\geq 0,76$ & Valid \\
\hline
\end{tabular}

b. Validation test for student book

The results of the student book assessment showed in the following table below.

Table 2

The validator rating result

\begin{tabular}{llll}
\hline No & Assessment Aspects & Validity Index of Aiken & Desc \\
\hline 1. & Content & Average $\geq 0,86$ & Valid \\
\hline 2. & Presentation & Average $\geq 0,81$ & Valid \\
\hline 3. & Language & Average $\geq 0,86$ & Valid \\
\hline 4. & Graph & Average $\geq 0,90$ & Valid \\
\hline
\end{tabular}

The validity index of Vaiken obtained from the nine validators' evaluations related to the student book was $\geq 0.81$, means that the students' worksheet could support project-based learning using simulation. Therefore, it was qualified to be implemented with some improvements.

c. Validation test for lecturer book

The results of the lecturer book assessment showed in the following table below.

Table 3

The validator rating result

\begin{tabular}{llll}
\hline No & Assessment Aspects & Validity index of Aiken & Desc \\
\hline 1. & Content & Average $\geq 0,81$ & Valid \\
\hline 2. & Presentation & Average $\geq 0,81$ & Valid \\
\hline 3. & Language & Average $\geq 0,86$ & Valid \\
\hline 4. & Graph & Average $\geq 0,86$ & Valid \\
\hline
\end{tabular}


The validity index of $\mathrm{V}_{\text {aiken }}$ obtained from the nine validators' evaluations for lecturer book was $\geq 0.81$, means that the lecturer book could support project-based learning using simulation. Therefore, it was qualified to be implemented with some improvements.

\section{d. Validation test for the research instrument}

The validity test for research instruments was included knowledge competency and attitude competency. The results showed in the following table below.

Table 4

The validator rating on the research instrument

\begin{tabular}{lll}
\hline Validity Instrument & Validity index of Aiken & Desc \\
\hline Knowledge competency & Average $\geq 0,76$ & Valid \\
\hline Attitude competency & Average $\geq 0,76$ & Valid \\
\hline
\end{tabular}

The validity index of $\mathrm{V}_{\text {aiken }}$ obtained from the nine validators' evaluations for the research instrument was $\geq 0.76$, means that the project-based learning using simulation met the content validity, so it is considered to be implemented at the trial stage with some improvements. Besides the attitude and knowledge competency instrument, the supporting instrument also validated with $\mathrm{V}_{\text {aiken }}$ index $\geq 7.6$.

Table 5

The validator rating on supporting instrument

\begin{tabular}{lll}
\hline Validity Instrument & Validity index of Aiken & Desc \\
\hline Syntax implementation & Average $\geq 0,87$ & Valid \\
\hline Questionnaires & Average $\geq 0,76$ & Valid \\
\hline
\end{tabular}

\section{Result of Assessment Phase}

In this phase, the effectiveness was tested for project-based learning using simulation in product trials.

\section{a. Product trial}

The trial subject was limited to 10 students. Questionnaires were used to measure the product probability of project-based learning. The instrument aspects given was feedback from students' responses about books and teaching materials to support project-based learning using simulation. Each aspect consisted of 7 questions and 5 questions with 1-4 scale rating. The results showed in the following table below.

Table 6

The result of lecturers and students' response

\begin{tabular}{lllll}
\hline \multirow{2}{*}{ Assessment Aspect } & \multicolumn{2}{c}{ Student } & \multicolumn{2}{c}{ Lecturer } \\
\cline { 2 - 5 } & Ps $(\%)$ & Category & Ps $(\%)$ & Category \\
\hline Students' sheet, material, and model & 74,64 & Good & 68 & Good \\
\hline
\end{tabular}

The results showed an average percentage score (Ps) of $74.64 \%$ with the category "Good" for students' responses. While the lecturer obtained an average percentage score (Ps) of 68\% with the category "Good". According to Riduwan (2008), for the percentage score $(\mathrm{Ps}) \geq 61 \%$ has a category "Good", which means that the model was qualified to be implemented. 


\section{b. Field trial}

The field trial is the implementation of models and support systems in the classroom. The number of subjects was 70 students. It tested the effectiveness and compatibility of the learning model. The effectiveness test was conducted by comparing the learning outcomes of the experimental class and the control class, each consisting of 36 students and 34 students. Experimental class students learn with project-based learning based on simulation, and control class students learn with conventional methods. Based on the dependent variable in this study, to prepare prospective, cultured, and characterized educators, the data obtained at this stage is attitudes and knowledge competency learning outcomes. Data on learning outcomes showed in the table below.

Table 7

Learning outcome

\begin{tabular}{lllll}
\hline \multirow{2}{*}{ Class } & Knowledge & \multicolumn{3}{l}{ Attitudes } \\
\cline { 2 - 5 } & Score Average & Category & Score Average & Category \\
\hline Control & 2,49 & Good & 73,06 & Good \\
Experiment & 2,95 & Good & 84,15 & Very good \\
\hline
\end{tabular}

The result showed that the attitudes and knowledge learning outcomes of the experimental class were higher than the control class. The data is then performed t-test analysis. It is intended to determine differences in the average learning outcomes of the experimental class and control class. The normality test and homogeneity test of the two classes are conducted before the t-test analysis. The effectiveness analysis showed in the following table.

Table 8

Analysis of the effectiveness test

\begin{tabular}{|c|c|c|c|c|c|c|}
\hline \multirow{3}{*}{ Types of test } & \multicolumn{3}{|l|}{ Knowledge } & \multicolumn{3}{|l|}{ Attitudes } \\
\hline & \multicolumn{2}{|l|}{ Sig. } & \multirow{2}{*}{$\begin{array}{l}\text { Data } \\
\text { conclusion }\end{array}$} & \multicolumn{2}{|l|}{ Sig } & \multirow{2}{*}{$\begin{array}{l}\text { Data } \\
\text { conclusion }\end{array}$} \\
\hline & $\begin{array}{l}\text { Experiment } \\
\text { class }\end{array}$ & $\begin{array}{l}\text { Control } \\
\text { class }\end{array}$ & & $\begin{array}{l}\text { Experiment } \\
\text { class }\end{array}$ & $\begin{array}{l}\text { Control } \\
\text { class }\end{array}$ & \\
\hline Normality & 0,200 & & Normal & 0,137 & & Normal \\
\hline Homogeniety & 0,148 & 0,020 & Homogen & 0,130 & 0,081 & Homogen \\
\hline Uji t & 0,040 & & different & 0,01 & & Different \\
\hline
\end{tabular}

Based on the result showed that the sig. (2-tailed) value of attitudes and knowledge learning outcomes is 0.05 , then $\mathrm{H} 0$ is rejected, which means that there are differences in the average learning outcomes of the experimental and control class. Differences influence the treatment given on the experimental class that treated using project-based learning on simulation. The research supporting this development research is the results by (Robb Sinn, Marnie Phipps, 2013), that stated simulations in higher education would bring up the culture during learning and improve character education and support local culture.

In project-based learning using simulation, the project is implemented by developing lesson plans integrated with the Minangkabau culture subject. Thus, students learn to 
express themselves by producing works through Minangkabau arts and cultural activities. Besides mastering the Minangkabau culture, learning encourages students' character and attitude to become cultured individuals.

The situation showed that implementing the Minangkabau traditional dances and Pituah (proverbs) performed on project-based learning using simulation can positively impact the learning outcomes. Project-based learning using simulation supports character education to prepare students as prospective and cultured educators in Minangkabau. According to Fajarini (2014), a professional education process can shape student's character. Explore and save various Minangkabau culture elements, including norms and customs that are useful and can function effectively in character education. Furthermore, Pernantah et al (2018), also researched the integration of values in learning by producing a model of learning based on Minangkabau cultural values that aim to develop character education and meaningful learning.

Also, Naqiyah et al (2019) have developed learning tools integrated with the Makassar community's local wisdom as a learning resource for students' needs. Parmin, et al (2019) also developed the Integrated Science Learning Model (SIL) for the development of Science Knowledge based on local wisdom from the Java North Coast Community (Pantura). Pernantah, et al (2018), developed a problem-based learning model based on the local wisdom in Oath Satie Bukik Marapalam (Minangkabau). Syaputra, et al (2018) developed and tested the effectiveness of the Problem Based Learning model and Value Clarification Technique based on the oral tradition value of Selimbur Caye, Bengkulu. From various studies, it is confirmed that local wisdom can play a significant role in developing learning to create learning innovations and character education.

Through the project, attitudes reflected in character education using simulation can form honest, obedient/disciplined, responsibility, cooperation, faithful and creativity, tolerance, courage, courtesy, caring, self-control, and self-confidence self-curiosity, enthusiasm, enthusiasm, love. The supporting instrument in the effectiveness test of the experimental class is the syntax of implementation. The results showed in the following table below:

Table 9

The result of syntax observation

\begin{tabular}{llll}
\hline Assessment & & Average & Category \\
\hline \multirow{2}{*}{ Syntax } & Lecturer & 80,36 & Good \\
\cline { 2 - 4 } & Student & 83,58 & Good \\
\hline
\end{tabular}

The syntax implementation assessment results get the category of "Good" both lecturers and students' activities, which means that the project-based learning using simulations is easy to use. Some of the obstacles faced are preparing students to show up because some are not fluent in the Minangkabau language. At this stage, the probability evaluation of project-based learning using simulations developed in the field trial also included the assessment aspects given, which is the students' responses to the learning implementation consisting of 15 questions. The results of student and lecturer responses showed in the following table: 
Table 10

The result of lecturer and students' responses

\begin{tabular}{lclcl}
\hline Assessment Aspect & Student & \multicolumn{3}{c}{ Lecturer } \\
\cline { 2 - 5 } & Ps (\%) & Category & Ps (\%) & Category \\
\hline $\begin{array}{l}\text { Students' book, lecturers' } \\
\text { book, and model of book }\end{array}$ & 80,88 & Good & 79,54 & Good \\
\hline
\end{tabular}

The result obtained an average percentage score (Ps) of lecturers and students respectively $87.28 \%$ and $92.04 \%$, with the category "Very Good". According to Riduwan (2008), the percentage score (Ps) $\geq 81 \%$ has the category of "Very Good", which means the model and the model support system developed is possible to use.

Table 11

The details of the findings in the form of products

\begin{tabular}{lllll}
\hline No & Assessment Variables & Average & \multicolumn{2}{c}{ Percentage Interpretation } \\
\hline & Easiness of Model Implementation- PBPS & 4,19 & $83,70 \%$ & Practical \\
\hline 1 & Benefits of Learning Models PBPS & 4,17 & $83,33 \%$ & Practical \\
2 & & & & \\
\hline 3 & $\begin{array}{l}\text { Usability of Student Books, PBPS Books, and } \\
\text { Lecturers' Books in Learning }\end{array}$ & 4,23 & $84,69 \%$ & Very Practical \\
\hline $\begin{array}{l}\text { Time Allocation } \\
\text { Holistic Average }\end{array}$ & 4,10 & $81,90 \%$ & Practical \\
\hline
\end{tabular}

The design of the S-PPA model which was developed through several processes was initiated from the design process, self-evaluation, validation by experts or experts, FGD and testing field through One-To-One Evaluation, Small Group, and Field Test. The development of the PBPS model is an innovation in learning Minangkabau culture which is not only oriented to increase knowledge students master Minangkabau culture, but its instructional impact desired is to increase the character values of students

\section{CONCLUSION}

The research results concluded that: 1) The project-based learning using simulation can be applied to students to develop learning tools. 2) The project-based learning using simulation was qualified to be implemented in learning. Based on the validator's evaluation, the learning model has fulfilled the content validity with $\mathrm{V}_{\text {aiken }} \geq 7.6$ and assesses both lecturers and students in the "Very Good" category. 3) Teaching and learning in project-based learning using simulation effectively improved the learning outcomes of students' knowledge and attitudes. The average value of student learning outcomes in the experimental class is higher than in the control class.

\section{RECOMMENDATIONS}

The project-based learning model based on local wisdom can be applied to senior high school. The project-based learning model based on local wisdom can also be implemented for another subject or study program. Finally, this model can also be tried for further research about local wisdom in specific respective regions, especially to the local wisdom of the Minangkabau Culture. The Simulation Project Based Learning 
Model (PBPS) has consequences that there is a need for a program to improve the competence of lecturers in subjects Minangkabau culture from college. This PBPS can serve as a guide for teaching Minangkabau culture at STKIP Padang. Minangkabau Culture Lecturers have limited abilities in practice, especially in the arts in Minangkabau. The research results show Minangkabau culture lecturers in terms of art practice in Minangkabau is very rarely implemented. Simulation ever there has not been able to improve the character values of students in tertiary institutions because the existing simulation is only held for one semester.

\section{ACKNOWLEDGMENT}

Conflict of Interest; Authors declare no conflict of interest within this research, publication paper, and research support. The research publication was supported by State University of Padang, West Sumatra, Indonesia.

\section{REFERENCES}

Afridinata, H., Samad, D., \& Kosim, M. (2018). Penguatan pendidikan karakter peserta didik melalui program pendidikan bernuansa surau dan budaya minangkabau. Turast: Jurnal Penelitian dan Pengabdian, 6(1), 48-66. https://doi.org/10.15548/turast.v6i1.687

Akker, J.V.D., Bannan, B., Kelly, A. E., Nieveen, N., dan Plomp, T. (2013). Introduction to educational design research. Enschede, . Netherlands : SLO.

Eisenhard, A, Ninassi., \& Susanne, B. (2018). The use of simulation and cases to teach real world decision making: Applied example for health care management graduate programs. International Journal Of Instruction, 12(1).

Ardianti, S. D., Pratiwi, I. A., \& Kanzunnudin, M. (2017). Implementasi project based learning (Pjbl) berpendekatan science edutainment terhadap kreativitas peserta didik. Refleksi Edukatika: Jurnal Ilmu Pendidikan, 7(2), 145-150. https://doi.org/10.24176/re.v7i2.1225

Arsih, F., Zubaidah, S., Suwono, H., \& Gofur, A. (2019). The exploration of educational value in randai minangkabau art, Indonesia. Journal for the Education of Gifted Young Scientists, 7(4), 1225-1248. http://dx.doi.org/10.17478/jegys.605463

Azwar, W., Yunus, Y., Muliono., \& Permatasari, Y. (2018). Nagari Minangkabau: The study of indigenous institutions in west sumatra, indonesia. Jurnal Bina Praja, 10(2), 231-239. https://doi.org/10.21787/jbp.10.2018.231-239

Barlenti, I., Hasan, M., \& Mahidin. (2017). Pengembangan LKS berbasis project based learning untuk meningkatkan pemahaman konsep. JPSI, 05(01), 81-86.

Borg, W.R. dan Gall, M.D. (1989). Educational research: An introduction, fifthy. edition. New York: Longman.

Dwiyogo, W. D. (2018). Pembelajaran berbasis blended learning. Depok: Rajawali Press. 
Eliza, D. (2017). Pengembangan model pembelajaran karakter berbasis cerita tradisional minangkabau untuk anak usia dini. PEDAGOGI: Jurnal Anak Usia Dini dan Pendidikan Anak Usia Dini, 3(3b), 153-163.

Eyikara, E. Z. G. (2017). The importance of simulation in nursing education. World Journal on Educational Technology: Current Issues, 9(1), 2-7.

Fadli, M. (2018). Transfer of Indigenous Knowledge : Pelestarian pengetahuan lokal pada institusi lokal bundo kanduang di minangkabau. Shaut al-Maktabah Jurnal Perpustakaan, Arsip dan Dokumentasi, 10(2), 177-182.

Febrina, R. (2017). The effectiveness of project based learning on students' social attitude and learning outcomes. Jurnal Pendidikan Teknologi Kejuruan, 23(4), 374-382. https://doi.org/10.21831/jptk.v23i4.14878

Firdaus, D. R. S., P.Lubis, D., Susanto, D., \& Soetarto, E. (2018). Potret budaya masyarakat minangkabau berdasarkan keenam dimensi budaya hofstede. Sodality: Jurnal Sosiologi Pedesaan, 6(2), 121-130.

Fransyaigu, R. (2015). Penerapan inkuiri moral berbasis nilai-nilai kearifan lokal minangkabau "alam takambang jadi guru" untuk pembentukan karakter siswa. Jurnal Inovasi Sekolah Dasar, 2(2), 92-99.

Garvey, B., \& Krug, M. (2015). Model-model pembelajaran sejarah di sekolah menengah (Terjemahan). Yogyakarta: Penerbit Ombak.

Joyce, Bruce; Weil, Marsha; \& Calhoun, Emily. (2011). Model-model pengajaran (Terjemahan Edisi Delapan). Yogyakarta: Pustaka Pelajar.

Mayasari, T., Kadarohman, A., Rusdiana, D., \& Kaniawati, I. (2016). Apakah Model Pembelajaran Problem Based Learning dan Project Based Learning Mampu Melatihkan Keterampilan Abad 21?. JPFK, 2(1), 48-55. http://doi.org/10.25273/jpfk.v2i1.24

Moleong, L. (2010). Metodologi Penelitian Kualitatif. Bandung: Rosda Karya.

Malik, R. (2018). Ikatan kekerabatan etnis minangkabau dalam melestarikan nilai budaya minangkabau di perantauan sebagai wujud warga NKRI. Jurnal Analisa Sosiologi, 5(2), 17-27.

Naqiyah, M., Rosana, D., Sukardiyono., \& Ernasari. (2019). Developing physics learning tools based on local wisdom in the form of musical instrumen of gandrang bulo dance as learning source in sound wave. Journal for the Education of Gifted Young Scientists, 7(3), 609-626. http://dx.doi.org/10.17478/jegys.599902

Nusi, A. \& Yelliza. (2020). Need analysis of ESC ( English short course) program for administrators in state polytechnic ambon. International Journal of English Education and Linguistics (IJoEEL), 02(02), 40-46. Probolinggo:UNUJA

Nurhayani. (2017). Penerapan metode simulasi dalam pembelajaran fikih ibadah bagi siswa di MTS YMPI sei tualang raso tanjung balai. Jurnal ANSIRU, 1(1), 88-104. 
Parmin, P, Nuangchalerm, P., \& El Islami, Z. (2019). Exploring the indigenous knowledge of java north coast community (Pantura) Using the Science Integrated Learning (SIL) Model for Science Content Development. Journal for the Education of Gifted Young Scientists, $7(1), \quad 71-83$. http://dx.doi.org/10.17478/jegys.466460

Pernantah, P. S. (2018). Pembelajaran Sejarah Terintegrasi Nilai Local Wisdom. Yogyakarta: Phoenix Publisher.

Pernantah, P. S., Sariyatun., \& Warto. (2018). Integration sumpah satie bukik marapalam values in historical learning through problem-based learning. International Journal of Multicultural and Multireligious Understanding (IJMMU), 5(3), 28-34. http://dx.doi.org/10.18415/ijmmu.v5i3.138

Robb, S., \& Marnie, P. (2013). Mathematics career simulations: An invitation. ijSOTL, $1-13$.

Saied, H. (2017). The impact of simulation on pediatric nursing students' knowledge, self-efficacy, satisfaction, and confidence. Journal of Education and Practice, 8(11), 95-102.

Sucipto, H. (2017). Penerapan model project based learning untuk meningkatkan minat dan hasil belajar IPS. Jurnal Pendidikan: Riset \& Konseptual, 1(1), 77-86.

Susan Galloway, C. N. (2009). Simulation techniques to bridge the gap between novice and competent healthcare professionals. OJIN ANA, 14(2). http://dx.doi.org/10.3912/OJIN.Vol14No02Man03

Syaputra, E., Sariyatun., \& Sunardi. (2018). The strategy of enhancing student's social awareness through history learning based on selimbur caye oral tradition values. International Journal of Multicultural and Multireligious Understanding (IJMMU), 3(4), 22-29. http://dx.doi.org/10.18415/ijmmu.v5i4.161

Wicaksono, G. W., Asrini, H. W., \& Al-Rizki, M. A. (2017). Desain perangkat pembelajaran pendidikan tinggi dengan sistem lective gegulang ${ }^{\text {TM}}$. JNTETI, 6(4), 416422.

Zulfa \& Jufrizal. (2020). Budaya Minangkabau (Peradaban Dan Nilai-Nilai Pendidikan Generasi Muda). Seminar Nasional Fakultas Ilmu Budaya Universitas Andalas (pp. 110). Padang: FIB Press Unand.

Zulfa, Z. (2019). Contextual Learning of Karakter Values In Minangkabau Culture Course To Strengthen National Identity. Journal of Moral and Civic Education, 3(1), 38-47. http://dx.doi.org/10.24036/8851412312019106 